\title{
Civic Education: An Instrument for Self-Reliance in Nigeria
}

\author{
Owuamanam Catherine Nkechinyere \\ National Institute for Nigeria Languages, Aba-Abia, Nigeria
}

\begin{abstract}
This study examined civic education as an instrument for self-reliance in Nigeria. The researcher was faced with the problem of high unemployment and under employment rate in Nigeria even when the country is trying hard to provide equal educational opportunities for all. The objectives of the study are to find out the relevance of civic education in actualizing self-reliance in Nigeria and the challenges of civic education in Nigeria. Two research questions were addressed to guide the study. The area of the study is South-East of Nigeria. The sample of the study constituted 100 civic education teachers drawn through stratified simple random sampling technique. A 20-item questionnaire was used to collect data on the respondents. The instruments were validated by two experts in educational technology and one from measurement and evaluation from National Institute for Nigeria Languages, Aba. The instrument yielded 0.84 by using Cronbach Alpha method. The results were analyzed by using mean scores. The findings of this study on the relevance of civic education in actualizing self-reliance in Nigeria indicate that civic education is a means through which citizens are librated from ignorance and equipped with needed skills, political, economical, social, and administrative consciousness, which is necessary to facilitate and maintain national consciousness, it develops in the citizens good values, patriotism, and provokes in them the determination to become good citizens and it enlightens, educates, and helps in individual intellectual development. The findings of the study also showed that the challenges of civic education in Nigeria include: paucity of fund, problem of inadequate planning in the system, insufficient instructional resources, shortage of manpower, and problem of imbalance between theory and practice. However, it was recommended among others that the Federal Ministry of Education (FME), State Ministries of Education (SMOEs), and Federal Capital Territory (FCT) should include civic education course in all disciplines, states, and FCT to collaborate with Nigeria Education and Research Development Council (NERDC) to build the capacity of teachers in civic education and skill acquisition rather than mere memorization of scattered prices of information.
\end{abstract}

Keywords: civic education, self-reliance, instrument

\section{Introduction}

Education is at the heart of national development and quality human capital development. Development, on the other hand, is a multi-dimensional process involving reorganization and reorientation of the entire economic and social systems (Ugwu, 2017). Education is life of a nation. This is because it unlocks the economic potentials of the people, empowers and equips individuals in society to participate in and benefit from their national economy, facilitates economic development, and provides the basis for transformation (Sule, 2014).

Owuamanam Catherine Nkechinyere, Ph.D., School of Education, National Institute for Nigeria Languages. 
According to Ugwu (2017), education means what each generation gives to its younger ones which make them develop attitudes, abilities, skills, and other behavioural attributes, which are germane to the growth of the society in which they live. It is the instrument used for the development of human beings in the cognitive, affective, and psychomotor domains. This is achieved through the process of teaching and learning.

Therefore, education can be used as a tool for achieving a united, strong, and self-reliant nation. A self-reliant nation is one which solves its developmental problems by using human and material resources predominantly sourced from within its borders (Okojie, 2018). A self-reliant person is a respected person in the society. Self-reliant is the ability to depend on yourself or your own abilities (Vocabulary, 2018). It implies having confidences in one's own powers, skills, abilities, or judgment (Meneke, Onyenwigwe, \& Elemuwa, 2009). Self-reliant is a means of maintaining ones pride and dignity (Okojie, 2018). The basis or argument for self-reliance is that individuals are endowed with different skills, talents, and abilities. These skills, talents, and abilities need to be developed for the growth of individuals and society. These skills, talents, and abilities could be developed through civic education.

Civic education is that form of education, which is primarily designed and organized in content and function, so as to produce good and useful people who know what events happen within the country and globally (Ukaegbu \& Anyaoha, 2014). Civic education is a result of government decision to lead its citizens in different geographical and political communities to acquire some kinds of knowledge, facts, skills, abilities, values, virtues, attitudes, and behaviours that are acceptable in society and useful in building a balanced and great nation. So, civic education is the education that aims at inculcating moral, values, skills, and attitudes in an individual with the desire or consciousness to use their abilities to solve developmental challenges facing a nation.

However, there are some challenges militating against the teaching and learning of civic education in Nigeria. These may come from the government, curriculum planners, parents, teachers, schools, and even from certain unpredictable environmental forces which are external. Unless these problems are looked into the realization of the aims and objectives of civic education in achieving self-reliance in Nigerian will be a mirage. It is against this background that the researcher looks at how civic education can serve as an instrument for actualizing self-reliance in Nigeria.

\section{The Statement of the Problem}

The implication of the declining quality of education in Nigeria at all levels has far reaching negative impact on the nation's moral, civic, cultural, and economic sustainability. This decline could be as a result of wrong type of education given to learners, which is not capable of bringing about self-sufficiency.

\section{The Objectives of the Study}

The objectives of the study are as follows:

1. To find out the relevance of civic education in actualizing self-reliance in Nigeria;

2. To find out the challenges of civic education in Nigeria.

\section{Research Questions}

This study is guided by two research questions:

1. What is the relevance of civic education in actualizing self-reliance in Nigeria?

2. What are the challenges of civic education in Nigeria? 


\section{Literature Review}

\section{Self-Reliance}

Self-reliance is commonly understood as the individual relying on oneself for every aspect of survival, development, and sustenance. According to Collins Co-Build Advanced English Dictionary (2018), "self-reliance is the ability to do things and make decisions by yourself without needing other people to help you”. Self-reliance is a quality of depending on yourself for things instead of relying on others (Vocabulary, 2018). When people have self-reliance, they are independent and autonomous. In other words, they take care of themselves. Some of us develop self-reliance as children when we start to prepare food for ourselves, take bus alone or in other ways exert our independence.

Self-reliance is the quality of not needing help or support from other people. It is also the ability to depend on yourself or your own abilities (Cambridge Dictionary, 2018). Self-reliance is the ability to think and act without the help or influence of others, the ability to decide what you should be or do (Community Empowerment Network, 2018). According to Cambridge Advanced Learners Dictionary and Thesaurus (2018), learning self-reliance is a slow and hard process. We expected it to take years of painful and stressful experiences when we will develop ourselves socially, economically, and philosophically. Man's life involves, therefore, the ability to acquire those things that are required to sustain one's basic experience as well as to enable one to achieve integrity, self-actualization, and respect.

Self-reliance implies having confidence in one's own powers, skills, abilities, or judgment. In other words, it means somebody working in such a way that he or she is not ashamed of his/her actions or decisions. It could be likened to somebody being independence or accountable to oneself (Meneke et al., 2009). The basis or argument for self-reliance is that individuals are endowed with different skills, talents, and abilities. These skills, talents need to be developed for the growth of individuals and society. Individuals are gifted in different talents. These are artistic, creativity, dedication, responsibility, and resourcefulness. Someone who is artistic is endowed with the skill and imagination for art works. It is one of the attributes of self-reliance in that a person that displays natural skills in or enjoyment of art is prone to be self-employed. Creativity here implies the ability to use your imagination or skills to produce new ideas and make things. Dedication implies hard work or effort that someone puts into a particular activity, because they care about it a lot. Responsibility means somebody being committed to a duty and taking care to ensure that the job is duly discharged. Finally, resourcefulness implies being good at finding ways of dealing with practical problems.

The rewards for every individual who finds the courage and strength to be self-reliant are magnificent. According to Simple Luxurious life (2018), they are as follows:

1. It will help the individual to discover the unique gifts that want to be realized;

2. The individual will become truly fulfilled and content;

3. The individual will become empowered;

4. It will help the individual to reach his full potential;

5. It is a refusal to conform mindlessly;

6. It helps the individual to develop strength;

7. It helps the individual to cultivate a strong character;

8. It promotes happier relationship; 
9. It is a step into an individual's greatness;

10. It brings more "luck" in an individual's life.

Self-reliance helps to improve the material or economic well being of the family. It also lifts the image of the family high, for example, Kalu Nwankwo's family and Jay-Jay Okocha’s family. Self-reliance helps a country to be economically, politically, and technologically independent of other countries. It also helps in the industrialization and development of the society (Meneke et al., 2009).

Finally, it is when one's self-concept adequately reflects reality that one is able to achieve fulfillment in life. Therefore, self-fulfillment is the end-product of self-development which involves the development of skills, adoption of attitudes, awareness of the right approaches to enhance our capacities to cope with life (Okojie, 2018).

\section{Meaning of Civic Education}

The world "civic" is a Greek word which implies citizens of a city or an area. Therefore, civic education is that form of education, which is primarily designed and organized in content and function, so as to produce good and useful people who know what events happen within the country and globally (Ukegbu \& Anyaoha, 2014). Civic education is a result of government decision to lead its citizens in different geographical and political communities to acquire some kinds of knowledge, facts, skills, abilities, values, virtues, attitudes, and behaviours that are acceptable in society and useful in building a balanced and great nation (Ukaegbu \& Onyaoha, 2014).

According to Oxford Dictionary of English (2014), "Civic education is a school subject which studies the way government works and deals with right and duties that you have as a citizen and as a member of a particular society”. Civic education, therefore, is a subject that studies rights, duties, and obligations of citizens in the society. It also studies the way the government operates as well as organs and institutions of government.

Civic education is the process of developing people positively towards knowing their rights, duties, and obligations to the state. It helps to evoke in the people economical, political, social, and administrative culture for the continual existence of the state. Civic education also positively develops among people values and norms that will encourage national integration and national unity (Meneke et al., 2009). These values includes patriotism, religious tolerance, total allegiance to the state, obedience to the law, and maintaining good relations with other ethnic groups. It also exposes the people to have full knowledge of the activities of government.

Civic education is a concept evolved to help develop high moral standard among citizens (Meneke et al., 2009). This is essential for the sustenance of the state and training of people who are democratically, politically, economically, and socially conscious and ever ready to participate in government activities and offer constructive criticisms where necessary.

The objectives of civic education are as follows (Meneke et al., 2009):

1. To understand the rights and privileges of citizens;

2. To equip the citizen with the skills to deal with various social and personal issues;

3. To equip individuals with an appreciation of the rights of other citizens;

4. To help citizens acquire values, norms, knowledge, actions, and activities necessary for and to achieve millennium development goals;

5. To enable the youths develop into responsible citizens;

6. To promote and encourage religious and political tolerance. 
The importances of civic education to the citizens are as follows:

1. Civic education is the means through which citizens are liberated from ignorance and equipped with needed skills, political, economical, social, and administrative consciousness, which is necessary to facilitate and maintain national consciousness (Ukaegbu \& Anyaoha, 2014);

2. The subject enables the youth to acquire knowledge, skills, and attitudes necessary to be responsible human beings in the society;

3. It helps individuals to abhor and reject negative social behaviour like stealing, cultism, prostitution, drug abuse, and so on;

4. It helps individuals to learn how to live peacefully in the society;

5. The knowledge of civic education is a necessary condition for social and political stability and good governance;

6. The knowledge of civic education promotes the practice of rule of law, which is an importance principle of democracy;

7. Through civic education, citizens are taught the national anthem, national pledge, and national symbols all of which are good instruments for national consciousness and identity;

8. It helps people to imbibe and acquire positive values;

9. The knowledge of civic education helps to develop in an individual a high moral standard (Meneke et al., 2009);

10. It enlightens, educates, and helps in individuals intellectual development;

11. It is a training platform for good and patriotic future leaders in many sphere of human endeavour.

The knowledge of civic education can be acquired through both formal setting like school and informal settings like families, villages, communities, town union meetings, churches, work places, non-governmental organization (NGOs), unions, political parties, mass media, sports teams, campaigns, and elections. There are also various ways/methods students can learn the subjects. The methods are as follows (Meneke et al., 2009):

1. Expository method: The students can acquire the knowledge of civic education through explanation of the contents by their teachers and resource persons. By using the expository method, the teacher impacts skills and knowledge of the subjects to the students.

2. Enquiring method: The knowledge of the subject can also be learnt through the students' effort to find out information by themselves. Information gathered through discovery form a major source of learning.

3. Observation method: Knowledge of civic education can be acquired by watching somebody or something carefully for a very long period of time. For example, through participation and observation in cultural activities, marriage festivals, and educational activities.

4. Research method: The outcome of this method is wonderful. By using this method, the students carry out a detailed study on a particular area of interest through systematically controlled activity.

5. Audio visual method: Another enriching source of knowledge is the information acquired through media like radio, television, and Internet.

6. Excursion method: Students can gather knowledge through experience acquired from visits to places like zoo, banks, companies, and museum.

7. Interview method: Teachers can arrange for interview sessions for student. During the interview, students can ask questions to resource persons. In the course of the responses, students gain knowledge. 


\section{Challenges of Civic Education in Nigeria}

Education is the training of the entire person to enable him not only to be able to read and write and calculate or to be proficient in a given job, but also to enable him to fit himself for living in a society (Okojie, 2018). Quality civic education could play a vital role in equipping individuals with some kinds of knowledge, facts, skills, abilities, values, virtues, attitudes, and behaviours that are acceptable in society and useful in building a balanced and great nation.

However, what is quite essential is the extent to which the civic education programme can be implemented to realize these goals. The programme is faced with a lot of challenges which will bring a setback in the attainment of its objectives. These challenges have not enable Nigeria to enjoy the advantages of this programme as expected.

Some of these challenges are as follows:

Paucity of funds. A major problem facing civic education programme in Nigeria is that of providing funds for its implementation. Civic education has not been fully implemented. Many schools have not got adequate supply of equipment and teachers for the teaching of the civic education. The implementation of civic education has not got adequate attention and sponsorship by government, because funds are not usually available (Okojie, 2018). For example, to introduce a new education programme a number of workshops must be held in order to bring together experts in the field of learning. The results of the deliberations by these experts must be widely published to afford members of the public the opportunity of following the new trends in the developments of the educational progamme in Nigeria. To teach a new educational programme at all levels of education, the teachers or instructors both old and new employed have to receive further training in teaching the new knowledge. In addition, new experts have to be trained locally and abroad, while some experts have to be recruited from abroad in such disciplines where qualified Nigerians are not available. All these projects depend on the availability of funds. The picture in Nigeria today is that funds are not sufficiently available for the kinds of activities described above. The introduction and retention of the Structural Adjustment Programme (SAP) and the Foreign Exchange Markets (FEM) tend to worsen the situation. Also, the abrupt decline of crude oil affects the funds of education in Nigeria.

There is the problem of inadequate planning. Strategic planning is a process that enables us to set targets and identify the means by which we can achieve such targets. In other words, it enables us to identify where we want to be at specific points in time and how to get there. Unfortunately, however, our strategic plans whenever they are evolved are not based on available data nor do they relate to the outcome of research findings (Jimoh, 2009). Most of the time, such plans and policies are announced before any form of planning is done and this is why, in the education sector especially, there is lack of continuity, leading to the begin-again syndrome. This syndrome is affecting civic education programme in Nigeria seriously.

Insufficient instructional resources. In the majority of Nigeria secondary schools, there are inadequate physical facilities and instructional resources. As a result of the large enrolments in these schools, the classrooms are usually over crowded with up to sixty or more students receiving instructions in classroom designed for 30 or 40 students. In most cases, the chairs and desks are not enough. You see those sharing chairs, standing up or setting on window, broken desks, and the floor (Jimoh, 2009). In some schools, students receive their lessons under shades of trees or in dilapidated structures provided by the communities. Also, some schools do not have equipped science laboratories and special rooms for teaching such basic subjects like civic 
education, entrepreneurial education, and introductory technology. Their libraries are not equipped with essential books, current journals, and magazines. In such cases, teachers cannot put in their best and students too cannot derive maximum benefit from the instructions being given. For effective teaching and learning, well equipped laboratories, libraries subject rooms, and good physical facilities are needed. But unfortunately, these are lacking in many Nigeria schools today (Jimoh, 2009).

Shortage of manpower. In Nigeria, the poor working condition, poor remuneration, and allowances, the teachers are subjected to have discouraged capable and qualified teachers from taking up the teaching jobs. They rather apply for other better paying jobs than teaching. Few teachers who have taken up to teaching profession did so due to lack of better jobs. According to Jimoh (2009), there is acute shortage of qualified teachers to handle majority of the courses. He revealed that National Policy on Education (NPE) wants all teachers in our educational institutions be professionally trained. To him, this has not been implemented. Also, adequate measures are not taken by the Ministry of Education to ensure that every teacher undergo a continuous periodic training programme to keep them in tune with modern practices.

Problem of imbalance between theory and practice. There is imbalance between theory and practice of civic education. Teachers can only teach and demonstrate civic education skills if they are properly grounded in the theory and practice of civic education skills. A good civic education programme ensures a balance between acquisition of relevant knowledge and psychomotor skills. The teaching and learning process must cover the cognitive, affective, and psychomotor domains (Jimoh, 2009). When a teacher concentrated on cognitive skills to the detriment of psychomotor skills development, then the learning outcome of the learner is without the needed balance between theory and practices.

Inadequate motivation for available teaching and non-teaching staff. Inadequate motivation for all teaching staff has affected staff efficiency, retention, creativity, and initiative in Nigeria. Many states in Nigeria owe their teacher's salary. This has resulted in teachers going on strike at any time and not contributing efficiently in the overall training of the students for a hungry man is an angry man (Jimoh, 2009). Equally, late payment of the salary of teachers discourages the teachers from putting in their best. Again, because of the comparatively poorer conditions of service of teachers in the Nigerian society, the tendency for many teachers in the nation's schools today is to use the teaching profession as a stepping stone to other highly esteemed and more attractive jobs. In consequence, teaching is gradually becoming a profession for fresh graduates in universities and colleges of education who are ready to call it quit as soon as they find greener pastures elsewhere. This does not help the development of the education system in Nigeria (Obioma, 2010).

There is the share explosion in the number of school-going children, leading to high enrolment rates, which are not matched correspondingly by the available infrastructure and instructional resources. And so, even if we had quality teachers who are able and willing to impact quality education (which we do not have anyway), the share size of the classes would make this impossible (Jimoh, 2009).

Poor standard of living and bad governance. This is a challenge to education in Nigeria which in turn affects the implementation of civic education programme. Children that are from poor homes do not go to school, because their parents cannot afford the fees. Many of them tend to hawking on the streets and doing other menial jobs to make ends meet. Parents, instead of sending their children to school, prefer to send them to hustle for their school fees on the roads. This has reduced drastically the standard of education in Nigeria. Also, bad governance we have in Nigeria is equally hitting down the educational system. The government does not 
encourage the students and pupils with scholarship and other incentive that will motivate them to struggle higher (Obioma, 2010).

High level of corruption in Nigeria. In Nigeria, corruption and embezzlement of public funds have given way to economic, social, and educational crises. The government owes teachers their salaries for months. Building and equipping of libraries and laboratories in our schools are never done. Instead, the rulers indulged in looting public funds for their selfish interest. Students and their parents will not ordinary want to be held back by any form of deficit or failure in any of the required subjects, hence, they go extra length in ensuring success. In some cases, some teachers at the secondary school level are involved by way of encouraging students to contribute money (cooperation fees) in order to secure the needed assistance during examinations.

Poor maintenance culture in the education system. In some states of Nigeria for the past 10 years, not even a single structure has been added to the existing one or a significant maintenance, repairs, or replacement of bad instructional facilities rather the responsibility of school ownership and funding are being shifted (Obioma, 2010).

\section{Method}

The design adopted for this study was descriptive survey, which was used to obtain information from the respondents. The design is chosen, because the study seeks to collect data on the particular features of a given population in a systematic manner such that the findings are expected to be generalized to the entire population (Nwogu, 1991). The area of study was South East of Nigeria. The sample of the study constituted 100 civic education teachers drawn through stratified simple random sampling technique. A 20-item questionnaire was used to collect data on the respondents. Items 1-10 were based on the relevance of civic education in actualizing self-reliance in Nigeria. Items 11-20 were based on the challenges of civic education in Nigeria.

The instrument was structured on a 4-point Likert Scale on which the respondents acted on. The items in the questionnaire were weighted as follows. "Strongly agree (SA) - 4 points", "Agree (A) — 3 points", "Disagree (D)—2 points", and "Strongly disagree (SD)—1 point". The criteria means was 2.50. The instrument was face validated by two senior lecturers in educational technology and one in measurement and evaluation, all from National Institute for Nigerian languages, Aba. The Cronbach Alpha coefficient method was used to determine the reliability of the instrument. It yielded a co-efficient of 0.83 with overall reliability of 0.84 . A total of 100 copies of the instrument were administered and retrieved. The data was analyzed by using mean scores. Any item with a rating of 2.50 and above was accepted value while item with a mean rating below 2.50 was rejected.

\section{Results}

The results of the data collected from the study are presented in Tables 1 and 2 according to the research questions.

\section{Research Question One: What is the Relevance of Civic Education in Actualizing Self-Reliance in Nigeria?}

Data presented above in Table 1 shows that the respondents agreed that all these items are the relevance of civic education in actualizing self-reliance in Nigeria. All the items have mean scores of 2.50 and above which is the criterion mean of acceptance. The grand mean is 2.76 . 


\section{Research Question Two: What are the Challenges of Civic Education in Nigeria?}

Table 1

Relevance of Civic Education in Actualizing Self-Reliance in Nigeria

\begin{tabular}{|c|c|c|c|c|c|c|c|}
\hline$S / N$ & Items & SA & A & D & SD & Mean & Decision \\
\hline 1 & $\begin{array}{l}\text { It is the means through which citizens are librated from ignorance } \\
\text { and equipped with needed skills, political, economical, social and } \\
\text { administrative consciousness which is necessary to facilitate and } \\
\text { maintain national consciousness. }\end{array}$ & 160 & 90 & 40 & 10 & 3.00 & Accepted \\
\hline 2 & $\begin{array}{l}\text { It develops in the citizens' good values, patriotism, and } \\
\text { provokes in them the determination to become good citizen. }\end{array}$ & 120 & 90 & 40 & 20 & 2.70 & Accepted \\
\hline 3 & $\begin{array}{l}\text { It enlightens, educates, and helps in individuals' intellectual } \\
\text { development. }\end{array}$ & 80 & 120 & 50 & 15 & 2.65 & Accepted \\
\hline 4 & $\begin{array}{l}\text { It is essential for the existence and sustenance of democracy } \\
\text { since it teaches the citizens the basic tenets of democratic process, } \\
\text { principles, practices, and fosters in them the zeal to participate in } \\
\text { the political process. }\end{array}$ & 40 & 200 & 50 & 15 & 3.05 & Accepted \\
\hline 5 & $\begin{array}{l}\text { It encourages the youth to be patriotic and nationalistic in } \\
\text { words and in deeds. }\end{array}$ & 80 & 120 & 50 & 15 & 2.65 & Accepted \\
\hline 6 & $\begin{array}{l}\text { It emphasizes the need to be law-abiding and keep a peaceful } \\
\text { nation. }\end{array}$ & 40 & 135 & 60 & 15 & 2.50 & Accepted \\
\hline 7 & $\begin{array}{l}\text { With the knowledge of civic education, governance is made } \\
\text { much easier. }\end{array}$ & 80 & 120 & 70 & 05 & 2.75 & Accepted \\
\hline 8 & With it, effective and proactive leaders are produced. & 160 & 90 & 40 & 10 & 3.00 & Accepted \\
\hline 9 & $\begin{array}{l}\text { It helps individuals to abhor and reject negative social behaviour } \\
\text { like stealing, cultism, prostitution, drug abuse, and ethnic hostility. }\end{array}$ & 40 & 135 & 60 & 15 & 2.50 & Accepted \\
\hline 10 & $\begin{array}{l}\text { It enables the citizens to know what duties and obligations they } \\
\text { owe to the state and what state owes the citizens. }\end{array}$ & 80 & 120 & 70 & 05 & 2.75 & Accepted \\
\hline & \multicolumn{5}{|l|}{ Grand mean } & 2.76 & \\
\hline
\end{tabular}

Table 2

Challenges of Civic Education in Nigeria

\begin{tabular}{|c|c|c|c|c|c|c|c|}
\hline$S / N$ & Items & SA & A & $\mathrm{D}$ & SD & Mean & Decision \\
\hline 11 & Paucity of fund. & 160 & 90 & 40 & 10 & 3.00 & Accepted \\
\hline 12 & Problem of inadequate planning in the system. & 40 & 135 & 60 & 15 & 2.50 & Accepted \\
\hline 13 & Insufficient instructional resources. & 120 & 90 & 40 & 20 & 2.70 & Accepted \\
\hline 14 & Shortage of manpower. & 80 & 120 & 70 & 05 & \multirow{2}{*}{$\begin{array}{l}2.75 \\
2.70\end{array}$} & Accepted \\
\hline 15 & Problem of imbalance between theory and practice. & 120 & 90 & 40 & 20 & & Accepted \\
\hline 16 & Inadequate motivation for available teaching and non-teaching staff. & 160 & 90 & 40 & 10 & 3.00 & Accepted \\
\hline 17 & $\begin{array}{l}\text { The share explosion in the number school-going children, leading } \\
\text { to high enrolment rates which are not matched correspondingly by } \\
\text { the available infrastructure and instructional resources. }\end{array}$ & 140 & 200 & 15 & 15 & 3.05 & Accepted \\
\hline 18 & Poor standard of living and bad governance. & 80 & 120 & 70 & 05 & 2.75 & Accepted \\
\hline 19 & High level of corruption in Nigeria. & 160 & 90 & 40 & 10 & 3.00 & Accepted \\
\hline \multirow[t]{2}{*}{20} & Poor maintenance culture in the educational system. & 160 & 90 & 40 & 10 & 3.00 & Accepted \\
\hline & Grand mean & & & & & 2.85 & \\
\hline
\end{tabular}

Table 2 revealed that all civic education teachers agreed that all the above are the challenges of civic education in Nigeria, hence, the grand mean of 2.85 is greater than the criterion mean of 2.50 . 


\section{Discussion}

The findings of this study on the relevance of civic education in actualizing self-relevance showed that civic education is the means through which citizens are liberated from ignorance and equipped with needed skills, political, economical, social, and administrative consciousness. It enables the youth to acquire knowledge, skills, and attitude necessary to be responsible human beings in the society. Civic education helps individuals to abhor and reject negative social behaviour like steeling, cultism, prostitution, drug abuse, and so on. It helps individuals to learn how to live peaceful in the society. The knowledge of civic education is a necessary condition for social and political stability and good governance. Its knowledge promotes the practice of rule of law which is an important principle of democracy. Civic education encourages the youth to be patriotic and nationalistic in words and in deeds. It enlightens, educates, and helps individuals' intellectual development. Civic education helps people to imbibe and acquire positive values and finally it enables the citizens to know what duties and obligations they owe to the state and what state owe to the citizens. The relevance of civic education in actualizing self relevance in Nigeria was articulated by Ukaegbu and Anyaoha (2014), thus, it is that study which instills in the individual's mind the consciousness which fosters nation building through honesty, patriotic zeal, unity of purpose, economic freedom, and political participation. In line with the above, Meneke et al. (2009) observed that civic education deals on values and principles of transparency, participation, responsiveness, accountability, empowerment, and equity. The findings of the study also revealed that if all the challenges of civic education in Nigeria are tackled, Nigerian citizens will say bye-bye to unemployment and there will be peace in the nation. The problems include paucity of funds, inadequate planning, insufficient instructional resources, shortage of manpower, problem of imbalance between theory and practice, inadequate motivation for available teaching and non-teaching staff, share explosion in the number of school-going children leading to high enrollment rates, which are not matched correspondingly by the available infrastructure and instructional materials, high level of corruption in Nigeria, and poor maintenance culture in the educational system.

Based on the above responses from the teachers of civic education, it can be inferred that the use of civic education as an instrument for self-reliance in Nigeria have been stalled by these challenges. In line with the above, Okojie (2018) stated that implementation of civil education has not got adequate attention and sponsorship by government, because forces are not usually available. Jimoh (2009) maintained that strategic plans in Nigeria, whenever they are evolved are not based on available data nor do they relate to the outcome of research findings. Furthermore, Jimoh (2009) reiterated that there is acute shortage of qualified teachers to handle the subject and that adequate measure are not taking by the Ministry of Education to ensure that every teacher undergo a continuous periodic training programme to keep them in tune with modern practice .

\section{Conclusion and Recommendations}

The use of civil education as an instrument for self-reliance in Nigeria is a welcome development. This is because it will reduce high employment and underemployment rates in the nation .This will instill in the individuals mind the consciousness which foster nation building through honesty, patriotic zeal, unity of purpose, economic freedom, and political participation. Based on the forgoing, the researcher recommended as follows: 
1. The Federal Ministry of Education (FME), State Ministries of Education (SME), and Federal Capital Territory (FCT) should include civic education course in all disciplines. This will to a great extent assist in solving the problem of high unemployment and underemployment in Nigeria.

2. States and FCT to collaborate with Nigeria Education and Research Development Council (NERDC) to build the capacity of teachers in civic education.

3. Teaching and learning processes must now change as a result of the challenges posed by modern developments. Skills acquisition rather than mere memorization of scattered pieces of information should now be the goal of classroom processes. Learner-centered approaches will have to replace teacher centered approaches.

4. Teachers at all levels need to be adequately motivated and afforts need to be intensified to ensure proper professionalization of teaching. If so much is expected of them, then so much also should be given to them. Efforts must be made to ensure that the best materials go into the profession and the conditions of service be attractive.

5. States, the FCT and other relevant stakeholders should collaborate with FME in organizing a national advocacy/zonal programme for the popularization and implementation of Teacher Education Development Fund Account (TEDFA) in order to reposition teacher education and development in the country.

6. The FME, SME, and FCT should engage the services of NGOs, private sector, development partners, and other relevant stakeholders to sensitize the communities on the importance of civic education in turning round the lives of the youths and the communities.

7. Civic education teachers should be exposed to sensitization programmes like seminars, workshop, and conferences to broaden their intellectual horizon on the importance of self-reliance in the country.

8. Qualified teachers in civic education should be employed to handle the subject in our various schools in Nigeria.

9. The government and other stakeholders in civic education should provide adequate instructional materials for the teaching and learning of civic education. There should be quality assurance in terms of adequate classrooms and class size.

\section{References}

Cambridge Advanced Learners Dictionary and Thesaurus. (2018). Self-reliance. Retrieved 2018, from https://dictionary.cambridge.org/dictionary/english/self-reliance

Cambridge Dictionary. (2018). Self-reliance. Retrieved 2019, from https://dictionarycambridge.org/dictionary/english/ self-reliance

Collins Co-Build Advanced English Dictionary. (2018). Self-reliance. Retrieved 2019, from https;//www.collinsdictionary.com/dictionary/English/selfreliance

Community Empowerment Network. (2018). Why is self-reliance important for sustainable development. Retrieved 2019, from http://www.endruralpoverty.org/what-we-do/programs/Cclear/299-why-is-self-reliance-important-for-sustainable-developme nt

Jimoh, S. A. (2009, April). Quality education: A veritable tool achievement of the millennium development goals. In A paper presented at The Annual National Congress of all Nigerian Confederation of Principals of Secondary Schools (ANCOPSS), Ilorin.

Meneke, O. A., Onyenwigwe, P. I., \& Elemuwa, C. L. (2009). A complete course in civic education for Junior Secondary Schools (p. 23). Owerri: Ambix Printers Nigeria.

Nwogu, B. G. (1991). Educational research, basic, issues and methodology (p. 55). Ibadan: Wisdom Publishers Limited. 
Obioma, G. (2010, October). Nigerian's experience in technical and vocational education and training (TVET). Reforms, challenges and opportunities for global competitiveness. In A key note address presented at The 23rd Annual National conference of Nigerian Association of Teachers of Technology (NATT), University of Uyo.

Okojie, M. U. (2018). Social studies education as a tool for self-reliance in Nigeria. Retrieved 2019, from http://www.globalacademicgroup.com/journals/nact/Monday/333.pdf

Oxford Dictionary of English. (2014). Civic education. Retrieved 2018, from http://www.ugovin.com

Simple Luxurious Life. (2018). Sixteen benefits of self-reliance. Retrieved 2018, from https://www.the simpleluxuriouslife.com/podcast113/

Sule, M. (2014). The role of entrepreneurship education on job creation among youths in Nigeria. International Letters of Social and Humanistic Sciences, 15, 87-96.

Ugwu, S. C. (2017). Education and national development: Nigeria experience. Retrieved 2018, from http:/www.Global academic group.com/journal/knowledge20reviewugwu.Pdf

Ukagbu, M. N., \& Anayaoha, C. N. (2014). Basic civic education for secondary school (p. 6). Owerri: Meybiks Nigeria Publishers.

Vocabulary. (2018). Self-reliance. Retrieved 2019, from http://www.vocabulary. com/dictionary/self-reliance 